\title{
ASSUMPTIONS OF MAXIMAL INDIVIDUALISM IN THE TIME OF THE COVID-19 PANDEMIC: ETHICAL ASPECTS
}

\author{
EWA BAUM ${ }^{1} \&$ AGNIESZKA ŻOK ${ }^{2}$ \\ ${ }^{1}$ Poznan University of Medical Sciences, Division of Philosophy of Medicine and Bioethics, Rokietnicka \\ 8, 60-806, Poznań, Poland. ORCID: 0000-0002-0503-0562, Email: ebaum@ump.edu.pl \\ ${ }^{2}$ Poznan University of Medical Sciences, Division of Philosophy of Medicine and Bioethics, Rokietnicka \\ 8, 60-806 Poznań, Poland. ORCID: 0000-0002-5560-5432, Email: agzok@ump.edu.pl
}

ABSTRACT: Maximal individualism, which is currently a prevalent trend in the way many patients think, places high hopes in the achievements of biomedicine and assumes that everyone should always receive optimal medical care. Such an approach is in line with many normative and legal acts operating worldwide, including the Declaration of Human Rights. However, its feasibility and effectiveness in the time of the COVID-19 pandemic raises numerous ethical, social and economic dilemmas. The culture of prosperity and excess, characteristic of contemporary Western societies, makes it even more challenging to come to terms with this situation.

KEYWORDS: COVID-16, postmodernity, bioethics, medical ethics

\section{INTRODUCTION}

The $21^{\text {st }}$ century, as it began two decades ago, has been instantly deconstructed and the concept 'fluidity of postmodernity,' a sense of uncertainty towards the adventitious nature of being has, in a matter of weeks, become more literal than at the turn of the century (Bauman 2006: 150-162). The world has become even more fluid than Zygmunt Bauman could have predicted. Not only has the myth of inner security been 
overturned, which had rebuilt itself since the attacks on the World Trade Center, but also the faith in the reliability of the normative acts and ethical principles developed after World War II. The guaranty of medical care foreseen by the Universal Declaration of Human Rights strongly resonates with the assumptions of maximal individualism. These are based on the belief in the right of access to the latest achievements of medicine (Shi and Singh 2011: 113). Habits resulting from living in a culture of prosperity and excess make it difficult to come to terms with the changes we will have to face. Such changes concern access to the healthcare system, interpersonal relations and economic settings alike. Canadian researcher M. Warren notes that 'Ethicists can best help during a pandemic by working to minimize the number of difficult choices health care providers must make and ensuring that when they're made it's for the right reasons.' She also believes that 'The experience of SARS in Toronto and responses to COVID-19 in other countries suggest that ethicists should focus on early involvement to articulate relevant procedural and substantive values and embed these into response plans ... [whilst] building ethics capacity and developing tools and frameworks that will help healthcare providers live with decisions they will face' (Warren 2020).

\section{MORAL DILEMMAS RELATED TO THE PANDEMIC COVID-19}

In their daily work with other people and undertaking specific action, healthcare providers might find generally accepted ethical principles to be helpful in making professional choices. Such standards may be especially helpful in emergencies that may lead to various moral dilemmas. In such situations, ethics can be a very important tool in solving the potential problems that may arise when people are working to fulfil their medical responsibilities. Ethics is a philosophical discipline that includes a range of issues which deal with determining the essence of duty, or necessity of a moral nature. This concerns judgment that makes it possible to decide what is good or bad, what is the origin of the latter and how it can be overcome. The term ethics has several meanings. It is used to describe the theory of moral obligation (valuation of behaviour), as well as the theory of real value systems used in a specific community and the accepted ways of doing things, in other words, certain moral standards (ethos). It may also include beliefs, judgments, ways of doing things and moral practices accepted within a community (Ossowska 2000: 9-21). Despite codified standards, especially in emergencies, moral dilemmas may emerge. The term moral dilemma is understood as a situation where one needs to make difficult choices between alternatives, none of which are satisfying for the decision maker (Chyrowicz 2008: 9-15). Ewa Baum defines a moral dilemma as a situation where there is a conflict between two mutually equivalent but contradictory and exclusive forces. A moral dilemma is a situation $\mathrm{Z}$ (or a class of situations) requires undertaking or ceasing action $\mathrm{X}$ to resolve it. Certain moral reasons suggest that action $\mathrm{X}$ is good, whilst others, that it is morally evil. The reasons in favour of $\mathrm{X}$ by principle belong to a different moral orientation than those against $\mathrm{X}$, albeit there are certain exceptions. The arguments for and against $\mathrm{X}$ are unresolvable (Baum 2010).

Codes of ethics, including the Code of Medical Ethics, which are among the oldest 
codes of professional ethics in human history, were designed to help in the resolution of such a dilemma. B. Häring sees medical ethics as a systematic approach to identifying the ethos of the medical profession, and as an attempt to develop major ethical standards from the perspective of this profession (Häring 1994: 185-196). Of key significance in this respect is the Declaration of Geneva adopted in 1949 by the World Medical Association (WMA), which is to serve as a model for the Hippocratic Oath in the WMA member countries (Osińska 1992). T. Kielanowski draws attention to the variability of the ethics of the medical profession. Over the years, the relevant codes have been modified, which is an outcome of the advancement of biomedicine (Tulczyński 1975:8). An example of this are the restrictions on the modification of the human genome introduced in the late $20^{\text {th }}$ century (Convention on Human Rights and Biomedicine 1997). In Poland, the first codes of professional ethics in medicine began to emerge in the $19^{\text {th }}$ century. After World War II, the code of professional ethics for doctors was changed several times. Currently in force in the Code of Medical Ethics of 2 January 2004 (KEL). At present, the first articles of KEL require doctors to respect human rights and to care for the dignity of the profession, in addition to stipulating that the highest value to doctors is the patient's health. Doctors are forbidden to use their knowledge and skills in actions that are contradictory to their medical vocation. Article 3. lists in great detail the factors due to which a patient cannot be discriminated against (KEL 1994). A doctor is therefore obliged to respect a patient, regardless of age, sex, race, nationality, religion, social affiliation, material situation, political views or other conditions.

The coronavirus disease 2019 (COVID-19) is spreading around the world and governments are taking increasingly stringent measures to reduce the number of infections. China, from where the virus originates, introduced quarantines in areas with a high number of cases, whereas Italy, which now faces perhaps the most serious threat, is already fully quarantined. Some governments and medical associations recommend measures that take into account, among other things, the patient's chances of survival, life expectancy, age and 'value to society' (Spain). Thus, there are many moral dilemmas, beginning with the social obligations of national governments towards citizens, through the social obligations of individual professional groups, to the limits of the authorities' interference in and restriction of civil rights. It transpires that as a society raised in the ethos of human rights, we find it extremely difficult to give up certain habits, whether it is a morning cup of espresso in a cafeteria or Saturday shopping. Therefore, it seems that emergency situations require extraordinary ethical standards and that regular codes and moral principles are not enough. The speed at which COVID-19 is spreading makes it impossible to introduce special regulations to that would provide for planning ahead of the developments.

It is assumed, with great probability that the pandemic started in December 2019 from a single source: a 'wet market' in the Chinese city of Wuhan (Hui et al. 2020). Previous epidemics like SARS and MERS had a similar source (Hui et al. 2020). The symptoms of infection are fever, coughing and dyspnoea. Muscle pains, sputum production and sore throat are less frequent (Hui et al. 2020). While most cases cause mild symptoms, for some patients, especially the elderly and those suffering from chronic 
diseases, the infection causes severe pneumonia and multi-organ failure leading to death (Hui et al. 2020a). It spreads among people extremely quickly mainly by breathing in droplets from coughing and sneezing. By 26 March, 524,013 cases were reported worldwide by 26 March 2020, with the largest outbreak in Europe being in Italy, where 80,589 people have fallen ill so far (Worldometer 2020). The situation in Italy is currently critical and requires controversial ethical standards. About a week into the epidemic's peak, it became clear that ventilating patients who were extremely unlikely to survive meant denying ventilatory support to many who could (Rosenbaum 2020). In the event of extreme resource scarcity, there are many scenarios that will continue to be unsustainable from a moral point of view, especially in view of increased forecasting uncertainty. There are questions about who to help first (Rosenbaum 2020). A similar problem will have to be faced by Spain, where especially in poorer regions, there is a shortage of medical staff and ventilators (Legido-Quigley 2020).

The pandemic we are currently dealing with puts doctors in a situation where they have to triage, which is a typical feature of medical disasters (Christ et al. 2010). However, in the current situation this does not concern patients who cannot be transported to hospitals due to the injuries they have suffered. Such decisions have to be made because there are not enough beds and ventilators in hospitals.

Despite the advancement of science, for instance the possibility of treating genetic diseases through DNA modification, the rapidly spreading virus poses a threat that is as serious as it would have been in the early $20^{\text {th }}$ century. However, the moral dilemmas that arise today seem to be more difficult to solve (Żok 2019; Taubenberger and Morens 2006). The assumptions of maximal individualism we take for granted can be seen as another trait of the culture of prosperity and excess, which is characterized by the fulfilment of supra-basic needs and access to commodities that were once considered a luxury (Dziamski 2016). In the current situation, Western societies are not only afraid for their lives, wanting to keep themselves safe, for example, by excessive accumulation of goods, ${ }^{1}$ but they also fear being deprived of the right to basic medical care. Hospitals and clinics are limiting the number of patients, therapies and treatments for fear of the virus (Salwacka 2020). In the case of sudden health threats, when a pandemic takes on unpredictable proportions, the rationing of scarce medical resources is inextricably connected with numerous ethical dilemmas resulting from the conflict between the laws of economy and purely moral imperatives. The literature on healthcare rationing most often cites trifurcation, namely the so-called 'macro,' 'mezzo' and 'micro' (micro-rationing) level (Putato 2007). The macro level concerns the allocation of resources at national level (by governments and individual ministries), which may involve politicisation and purely theoretical disputes. The mezzo level refers to the distribution of resources within administrative districts and larger hospitals; hence the allocation of such resources is usually decided by local authorities. The last level of rationing medical measures and procedures, or micro-rationing, comprises all actions taken directly by medical personnel at institutional level (hospitals or other healthcare institutions). Thus, medical personnel have to face many decisions, some

\footnotetext{
${ }^{1}$ https://gospodarka.dziennik.pl/news/artykuly/6465737,koronawirus-covid-19-sklepy-limity.html
} 
of which are made intuitively, not entirely consciously.

Rudolf Klein lists a number of strategies that healthcare professionals use when they are forced to categorise patients. These include i) deterrence: a large number of administrative requirements that effectively discourage efforts to obtain treatment; ii) delay: extending the whole process of obtaining treatment; iii) dilution: interruption or termination of treatment; iv) denial: exclusion/selection of certain groups of patients from/for treatment; and v) deflection: referral to other medical services (Klein 1993). Other criteria of resource allocation and access to medical services are of a technical nature. These include performance, efficacy, outcome and classification of patients based on needs, merit, risk (risk of undertaking treatment), benefit (outcome of undertaking treatment), and the principle of saving a patient whose life is at stake (Putato 2007: 42-47).

The drastic increase in the number of patients in Italy and Spain results in a shortage of beds and ventilators in hospitals: the demand exceeds the capacity of medical institutions. As pointed out in Politico, the shortage of hospital resources faces medical staff with increasingly difficult choices. Anaesthesiologists and doctors have to decide which patients will have access to beds and ventilators, of which there is certainly not enough for all those who need them. In Italy, the decisive criterion is the chance of survival. In Spain, an additional criterion is the patient's 'value to society.' This is apparently related to the criterion of 'maximising the common good.' According to the document developed by the Bioethics Working Group of the Spanish Society of Internal Medicine (SEMI 2020) together with the Spanish Society of Internal Medicine (SEMI 2020), priority should be given to the most promising patients in terms of the QALY index which expresses life expectancy adjusted for quality. 'This is not only about survival, but also about the conditions in which the patient will live.' The document stresses, however, that the patient's age cannot be the only factor of health assessment and patients should be diagnosed 'globally.' This means that people who are dependent on the patient should be taken into account to maximise the benefits for as many people as possible. In the document, doctors refer to the 'emergency situation that justifies the proposals.' Whilst this is an example classic utilitarianism, it is in all cases associated with the fact that we are facing dramatic choices.

Aware of the poor condition of the health care system in Poland, we should wish for all healthcare professionals to be protected from such a situation. Unfortunately, the negligence of the last three months cannot be repaired. The observance of Human Rights, even during the epidemic, is the duty of the state. Obviously, the COVID-19 pandemic requires special measures and restrictions to prevent, or rather slow down the spread of the virus. State borders have been closed, public gatherings have been banned, freedom of trade and business has been restricted. Doctors and other healthcare professionals may be called upon to work to contain the epidemic. But despite the fact that the right to life and respect of human dignity cannot be suspended, under the provisions of the Act on Preventing and Combating Infectious Diseases and Infectious Diseases in People (Journal of Laws 2008, no. 234), the Polish authorities may grant themselves special rights, such as to refer individuals to compulsory work. This is mainly the case of doctors, diagnosticians, radiologists (the disease can be di- 
agnosed by x-ray and CT imaging of lesions in the lungs [Li and Xia 2020]) and nurses. They may be appointed by the Minister of Health and be required to work for up to three months at a specific healthcare institution (Journal of Laws 2019, 152). The only individuals excluded from work in conditions that carry the risk of infection during an epidemic are persons under 18 or over 60 years of age; pregnant women; parents/ carers of children under 18 years of age, including single parents/carers; persons who have been declared partially or completely unfit for work; disabled and chronically sick persons, or any other persons specified in Art. 2 of the Act of 31 July 1981 on the Remuneration of Persons holding State Functions (Journal of Laws 2019, 152). Excluded are also members of parliament and senators of the Republic of Poland.

Despite the restrictions imposed by the Minister of Health, certain human rights must not be violated, namely the right to freedom and the rights specified in the (Polish Constitution 1997) in: Art. 30 (human dignity); Art. 34 and 36 (citizenship); Art. 38 (protection of life); Art. 39-41.4 (humanitarian treatment); Art. 42 (legal liability); Art. 45 (access to courts); Art. 47 (personal assets); Art. 53 (conscience and religion); Art. 63 (petitions); Art. 48 and Art. 72 (family and children). These rights must not be violated under any circumstances.

It is difficult to reconcile compulsory work with concern for the safety for one's family and relatives. An analysis of healthcare professionals' statements in social media and on information portals shows that they are afraid of being referred to work in isolation wards due to the abovementioned concerns. ${ }^{2}$ Doctors of specialisations other than infectious diseases who have remained at work (many others are on sick or parental leave) are overworked and stressed, because they have no protection against infection, for example masks, which are given only to those who have direct contact infected patients. These concerns are emphasised by the District Medical Chamber in Warsaw (OIL), which officially opposes the changes made to the Polish law in connection with the pandemic. They believe that the regulations are being created too hastily, that they focus on absolute and ill-considered exploitation of doctors (of who there are not enough even in normal conditions) and that they do not amend the faults in the system. They complain about the chaos, problems with personal protective equipment and shortage of tests. Furthermore, it should be noted that they strongly oppose the provisions of the government's draft of the law amending certain laws on the healthcare system related to the prevention and combating of COVID-19, which boil down to the fact that even doctors who are nursing mothers, doctors who are mothers of toddlers, doctors who are parents can be forced, at any time, to work in order to contain the epidemic (OIL 2020). The media coverage of the doctors' and nurses' work conditions shows that they do not have any basic antiviral protection in the form of masks, goggles or visors or gowns (Głowacki 2020). Masks are sewed by volunteers, but although this help is extremely valuable, a dilemma arises concerning the citizens' constitutional right to healthcare, which has been shifted to members of the public and non-governmental organizations (NGOs).

\footnotetext{
${ }^{2}$ The analysis was conducted between 20 and 26 March on Facebook and Twitter, and the portals TVN, WP, Onet and Gazeta.pl.
} 
Such a dilemma, in the context of anti-violence organisations, was raised by Nancy Fraser, who criticized successive US governments for their nonresponse to current problems and passing on their responsibilities to non-governmental organizations (NGOs) (Fraser 2014). In Poland, this is exemplified by Great Orchestra of Christmas Charity (WOSP), which for over two decades has been supplying neonatal wards with lifesaving equipment (WOSP 2020).

This brings us back to the moral dilemma of a doctor appointed to work in an infectious ward. The conflict is multifaceted, and contradictions appear both on legal and ethical grounds. The duty to work in an epidemiologically dangerous place seems to contradict to the right to protect life.

Undoubtedly, a pandemic situation requires special measures to ensure a minimum of security for citizens. However, these solutions should be implemented rationally, after an interdisciplinary consultation. Our collective duty is to minimise the number of the difficult choices that healthcare providers must make in a time of a pandemic. Evidence from the COVID-19 pandemic and past outbreaks indicate that planning forward and preparation are key to fulfilling this duty. When avoiding difficult choices is not possible, the ethicists' duty is to ensure that healthcare providers and other decision makers are equipped with what they need to make decisions and to act (Warren 2020).

\section{CONCLUSION}

In the extreme conditions of a pandemic, maximalist individualism seems to be a utopian fantasy and social factors, including economic ones, often contradict moral precepts. In such cases, the law sanctified by tradition, salus aegroti suprema lex esto, where the patient's health is considered a doctor's highest priority, the good of the doctor is sometimes difficult neglected. This is a real challenge for health policies in all countries, where, on the one hand, the capacity of the medical vocation is understood as the priority of protecting human life and health, preventing diseases, treating the sick and providing relief from suffering, and, on the other hand, large-scale and effective implementation of these tents is a serious problem and in practice, turns out to be extremely difficult. To paraphrase the Latin motto: Si vis salutem, para contra morbum, ${ }^{3}$ or 'If you want to be well, be prepare to be sick. Despite sounding ominous, it is rather a warning and a bit for yourself for your illness, does not sound ominous to us, but rather a warning and at the same time a guideline for the future.

FUNDING: This research received no external funding.

CONFLICT OF INTEREST: The authors declare no conflict of interest.

\footnotetext{
${ }^{3}$ A direct reference to Vegetius, military historian and theoretician: Si vis pacem, para bellum, (If you want peace, be prepared for war).
} 


\section{REFERENCES}

Baum, Ewa. 2010. Komórki macierzyste jako bioetyczny problem współczesnej medycyny. Poznań: Wydawnictwo Naukowe UMP.

Bauman, Zygmut. 2006. Życie na przemiał. Kraków: Wydawnictwo Literackie.

Chyrowicz, Barbara. 2008. O sytuacjach trudnych, bez wyjścia w etyce. Kraków: Znak.

Convention for the Protection of Human Rights and Dignity of the Human Being with regard to the Application of Biology and Medicine: Convention on Human Rights and Biomedicine. 1997. https://rm.coe.int/168007cf98.

Christ, Michael et. al. 2010. Modern Triage in the Emergency Department. Deutsches Aerzteblatt Online. https://doi.org/10.3238/arztebl.2010.0892

Dziamski, Grzegorz. 2016. Kulturoznawstwo, czyli wprowadzenie do kultury ponowoczesnej. Gdańsk: Wydawnictwo Katedra.

Fraser, Nancy. 2014. Drogi Feminizmu. Warszawa: Wydawnictwo Krytyki Politycznej.

Głowacki, Witold. 2020. „Koronawirus. Pozostawieni sami sobie i kneblowani lekarze prowadzą wojnę partyzancką z epidemią.” Polska Times. Retrieved March 30, 2020 (https://polskatimes. pl/koronawirus-pozostawieni-sami-sobie-i-kneblowani-lekarze-prowadza-wojne-partyzancka-z-epidemia/ar/c1-).

Häring, Bernhard. 1994. „W służbie człowieka.” Ethos 1-2: 185-196.

Hui, David et. al. 2020. “The continuing 2019-nCoV epidemic threat of novel coronaviruses to global health - The latest 2019 novel coronavirus outbreak in Wuhan, China." International Journal of Infectious Diseases, January 14, 2020. https://doi. org/10.1016/j.ijid.2020.01.009

Klein, Rudolf. 1993. “Dimension of rationing: who should do what?” British Medical Journal 308-311. https://doi.org/10.1136/bmj.307.6899.309

Konstytucja Rzeczypospolitej Polskiej. 1997.

La Sociedad Española de Medicina Intensiva. 2020. Retrieved March 30, 2020 (https:// semicyuc.org).

Legido-Quigley, Helena et al. 2020. "The resilience of the Spanish health system against the COVID-19 pandemic.” The Lancet, March 18. DOI: https://doi.org/10.1016/ S2468-2667(20)30060-8

Li, Yan, \& Xia Liming. 2020. “Coronavirus Disease 2019 (COVID-19): Role of Chest CT in Diagnosis and Management.” AJR. American Journal of Roentgenology. https:// doi.org/10.2214/AJR.20.22954

Naczelna Izba Lekarska, Kodeks Etyki Lekarskiej. 1994.

Okręgowa Izba Lekarska w Warszawie. 2020. Sprzeciw OIL w Warszawie wobec rządowej propozycji zmian przepisów, https://izba-lekarska.pl/monitor-lekarski/oil-wsprawie-zmiany-ustawy-o-covid/

Osińska, Krystyna, ed. 1992. Refleksje nad etyką lekarską. Warszawa: Wydawnictwo Archidiecezji Warszawskiej.

Ossowska, Maria.2000. Normy moralne. Warszawa: PWN.

Pegoraro, Renzo et al. 2007. Hospital Based Bioethics. A European Perspective. Padva: PICCIN.

Rosenbaum, Lisa. 2020. "Facing Covid-19 in Italy - Ethics, Logistics, and Therapeutics on the Epidemic's Front Line.” The New England Journal of Medicine. https://doi. 
org/10.1056/NEJMp2005492

Taubenberger, Jeffrey and David Morens. 2006. "1918 Influenza: the Mother of All Pandemics.” Emerging Infectious Diseases. https://doi.org/10.3201/eid1201.050979

Salwacka, Sylwia 2020. "Koronawirus. Centrum onkologii zamyka poradnie i diagnostykę. Musimy chronić chorych nawet za cenę opóźnienia terapii." Gazeta Wyborcza. Retrieved March 30, 2020 (https://poznan.wyborcza.pl/poznan/7,36001,25792121,koronawirus-kontrachorzy-na-raka-centrum-onkologii-zamyka.html).

Shi, Leiyu and Douglas A. Singh, eds. 2011. The Nation's Health. London: Jones \& Bartlett Learning.

Spanish Society of internal Medicine. 2020. Retrieved March 30, 2020 (https:// www.emedevents.com/organizer-profile/spanish-society-of-internal-medicine-semi).

Tulczyński, Aleksander. 1975. Polskie lekarskie kodeksy deontologiczne. Warszawa: PZWL.

Ustawa o zapobieganiu oraz zwalczaniu zakażeń i chorób zakaźnych u ludzi z dn. 5 grudnia 2008, Dz.U. 2008 nr 234 poz. 1570

Warren, Maroka. 2020. “Roles of ethicists in covid-19 response.” Impact Ethics 18 March 2020. Retrieved March 30, 2020 (https://impactethics.ca/2020/03/18/roles-forethicists-in-covid-19-response/).

Wielka Orkiestra Świątecznej Pomocy, Rozliczenia Finałów i roczne sprawozdania finansoweFundacji. 2020. Retrieved March 30, 2020 (https://www.wosp.org.pl/fundacja/wazne/rozliczenia\#utm_source=strona \&utm_medium=banner).

Worldometers. 2020. Retrieved March 30, 2020 (https://www.worldometers.info/coronavirus/).

Żok, Agnieszka. 2018. „Troska czy opresja - współczesny dyskurs genetyczny w kontekście myśli transhumanistycznej.” Etyka 57: 87-99. DOI: https://doi. org/10.14394/37

\section{BIOGRAPHICAL NOTE}

Ewa Baum is associate professor at the Poznan University of Medical Sciences, Poland. She is interested in the advancement of modern biomedicine and its accompanying ethical contexts.

Agnieszka Żok is cultural expert, Doctor of Health Sciences, assistant professor in the Department of Social Sciences and Humanities at the Poznan University of Medical Sciences, Poland. Member of the Local Ethical Committee for Animal Experiments.

OPEN ACCESS: This article is distributed under the terms of the Creative Commons Attribution Non-commercial License (CC BY-NC 4.0) which permits any non-commercial use, and reproduction in any medium, provided the original author(s) and source are credited.

ARTICLE HISTORY: Received 2020-03-30 / Accepted 2020-04-XX 
